A number of recent studies have presented water quality datasets, many with a focus on the watershed scale. Steiner et al. (2009a, 2009b) and Sadler (2008) are examples. The entire Nashua dataset presented here is

\section{The Nashua agronomic, water quality, and economic dataset}

\author{
P. Heilman, R.S. Kanwar, R.W. Malone, L. Ma, J.L. Hatfield, and K. Boyle
}

\begin{abstract}
This paper describes a dataset relating management to nitrogen $(\mathrm{N})$ loading and crop yields from 1990 to 2003 on 36, 0.4 ha (1 ac) individually tile-drained plots on the Northeast Research and Demonstration Farm near Nashua, Iowa, United States. The field-measured data were used to calibrate the Root Zone Water Quality Model (RZWQM), and the results were summarized in a special issue of Geoderma (Ahuja and Hatfield 2007). With a comprehensive, long-term measured dataset and a model that simulates many of the components of the agricultural system, one can begin to understand the effects of management practices on $\mathrm{N}$ loading, crop yields, and net income to the farmers. Other researchers can use this dataset to assess the effects of management on similar tile-drained systems occurring some distance from Nashua, under alternative climates and soils, with other management systems, or with simulation models using different process representations. By integrating the understanding developed at Nashua with datasets from other highly monitored sites and other sources, progress can be made in addressing problems related to excessive $\mathrm{N}$ fluxes in the Mississippi Basin. An example 30-year RZWQM simulation of 18 management systems implies that significant management changes are needed to meet the goal of reducing $\mathrm{N}$ loads to the Gulf of Mexico by $45 \%$. This paper and the associated datasets are intended to be used in conjunction with the analyses and process descriptions presented in the Geoderma special issue. The datasets and additional explanatory materials are available for download at http:// apps.tucson.ars.ag.gov/nashua.
\end{abstract}

Key words: economic data-hypoxia—natural resource database-nitrogen loadingtile drainage
Reducing the size of the hypoxic zone in the Gulf of Mexico is an important national goal with significant implications for agriThe US Environmental Protection Agency recommends reducing the quantity of both nitrogen $(\mathrm{N})$ and phosphorus $(\mathrm{P})$ delivered to the Gulf of Mexico by $45 \%$, with a focus on the springtime load of $\mathrm{N}$, which is most correlated with the size of the hypoxic zone (USEPA 2007). The EPA report further notes that tile-drained agricultural subbasins contribute nitrate- $\mathrm{N}\left(\mathrm{NO}_{3}-\mathrm{N}\right)$ fluxes out of proportion to their area in the basin, and such subbasins "represent nearly all of the spring $\mathrm{N}$ flux to the Gulf.These subbasins represent the tile-drained, corn-soybean landscape of Iowa, Illinois, Indiana, and Ohio and illustrate that corn-soybean agriculture with tile drainage leaks considerable $\mathrm{N}$ under the current management system[s]" (USEPA 2007). culture in the Mississippi River Basin.
This paper contributes to the sixth step defined in the Mississippi River/Gulf of Mexico Watershed Nutrient Task Force Action Plan to "Coordinate, consolidate, and improve access to data collected by State and Federal agencies on Gulf Hypoxia and Mississippi/Atchafalaya River Basin program activities and results" (2008). Specifically, the objectives of this paper are to improve access to (1) data relating management to $\mathrm{N}$ loading and crop yields from 1990 to 2003 collected on 36, 0.4 ha $(1 \mathrm{ac})$ individually tile-drained plots on the Northeast Research and Demonstration Farm near Nashua, Iowa, United States (hereafter referred to as Nashua), (2) the parameterization of the Root Zone Water Quality Model (RZWQM) (Ahuja et al. 2000) for Nashua as described in a special issue of Geoderma (Ahuja and Hatfield 2007), and (3) budgets for each year's crop. unique in its detail about management inputs and effects on yields and $\mathrm{N}$ loading at the plot scale, the amount of simulation modeling effort for tile-drained conditions, and the existence of detailed budgets for each plot-year observation. Some of these data have been presented elsewhere. In addition to the Geoderma special issue, Kanwar (2006) described the average $\mathrm{NO}_{3}-\mathrm{N}$ loss and corn yields for crop rotation-tillage system combinations and crop rotation-nutrient application combinations at Nashua over the period from 1990 to 1998 . The contribution of this paper is to describe and make available plot-level data regarding management effects on tile flow, $\mathrm{N}$ concentration, $\mathrm{N}$ loading, as well as corn (Zea mays L.) and soybean (Glycine max [L.] Merr.) yields over 36 plots for 14 years; RZWQM simulations over 30 plots for 14 years; and budgets for all 504 observed plot years. Readers should note that this paper and the associated datasets are intended to be used in conjunction with the analyses and process descriptions presented in the Geoderma special issue. The datasets and additional explanatory materials are available for download from http://apps.tucson.ars.ag.gov/nashua.

\section{Materials and Methods}

Study Site. Figure 1 shows the spatial arrangement of the 36 study plots at Nashua $\left(43.0^{\circ} \mathrm{N}, 92.5^{\circ} \mathrm{W}\right)$. The plots were originally established in 1977, and tile drains were

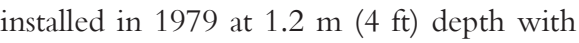
$28.5 \mathrm{~m}$ (94 ft) spacing between tile lines.

Philip Heilman is research leader of the USDA Agricultural Research Service, Southwest Watershed Research Service, Tucson, Arizona. Ramesh S. Kanwar is Charles F. Curtiss Distinguished Professor of Agricultural and Biosystems Engineering, lowa State University, Ames, lowa. Robert $W$. Malone is an agricultural engineer, and Jerry Hatfield is director with the USDA Agricultural Research Service, National Laboratory for Agriculture and the Environment, Ames, lowa. Liwang $\mathrm{Ma}$ is a soil scientist with the USDA Agricultural Research Service, Agricultural Systems Unit, Fort Collins, Colorado. Kevin P. Boyle is an agricultural economist and president of DevTreks (a nonprofit organization), Portland, Oregon. 


\section{Figure 1}

The 360.4 ha ( $1 \mathrm{ac})$ plots instrumented to measure nitrogen in the tile flow at Nashua. (Image created by i-cubed and provided by ESRI. Each pixel is equal to an area of about 15 $\mathrm{m}^{2}$ on the ground [i-cubed, Fort Collins, Colorado; copyright ESRI and its data provider. All rights reserved.])

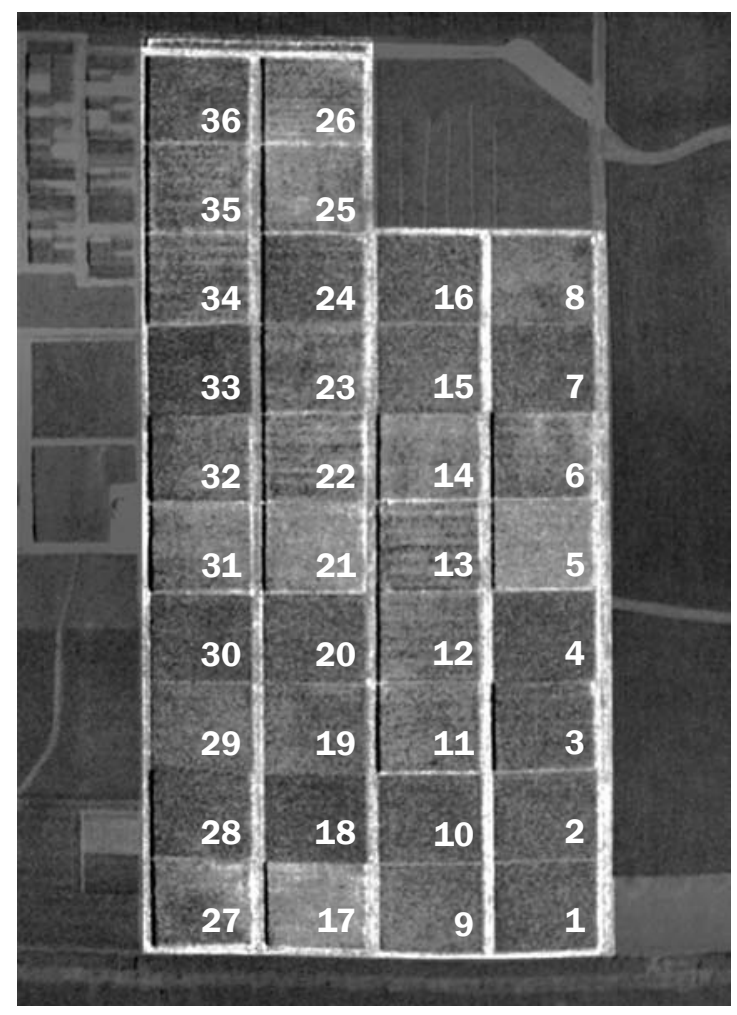

manure and UAN (urea ammonium nitrate) as sources of $\mathrm{N}$ for corn, $\mathrm{N}$ application rates and timing of $\mathrm{N}$ application, and use of a late spring $\mathrm{NO}_{3}$ test (LSNT) to determine the $\mathrm{N}$ fertilizer rate and $\mathrm{N}$ uptake efficiency by plants. Only two tillage practices were applied (chisel plow and no-till) to accommodate the additional $\mathrm{N}$ management treatments. From 1999 through 2003, the focus of the study shifted to manure application rate, timing, and method. Manure application rates were based on $\mathrm{N}$ or $\mathrm{P}$ needs for both phases of a cornsoybean rotation, either in the fall or spring. Each cropping season received manure and/ or UAN liquid fertilizer.

Table 2 summarizes a general categorization of $16 \mathrm{~N}$, tillage, and crop management systems at Nashua and the years they were studied. There is evidence (Malone et al. 2009) of a biennial yield effect, and there were some transition years. Consequently, a more detailed list of 35 management systems was also defined, shown in table 3. Corn and soybean rotations are split depending on whether the corn was grown in even (cornsoybean) or odd (soybean-corn) years.

Field Data Collection. The management practices used on each plot and year were recorded and are shown in table 4. Crop yields were collected in each year by plot. Subsurface drainage flow (tile flow) and $\mathrm{N}$ concentrations in tile water were sampled from a single drain passing through the middle of each plot. Drains along the sides of each plot were installed to prevent plots from influencing their neighbors, although variable tile flow indicated an unknown amount of lateral flow occurred in some plots (Ahuja and Hatfield 2007). Surface flow was not measured, but surface flow appeared to be very small for most plots based on measurements made on four plots only. Resource limitations at Nashua did not permit observations to close the water or $\mathrm{N}$ budgets. Pesticide concentrations in soil and tile flow were measured in some years, but were not considered in the RZWQM analysis presented in the Geoderma special issue (Ahuja and Hatfield 2007).

Root Zone Water Quality Model Parameterization. RZWQM is a comprehensive, state-of-the-science model to simulate physical, chemical, plant growth, soil, nutrient, pesticide, and management processes (Ahuja et al. 2000). RZWQM has been thoroughly evaluated using data from numerous locations, conditions, and
Additional information on each soil can be found in the official soil series descriptions
(NRCS 2006). Weather data (solar radiation Saseendran et al. 2007). with 6 years in each full set of treatments. A summary of the experimental desion is 2007b) and $\mathrm{Ma}$ (2007c). Prior to 19 field experiments focused on moldboard plow, chisel plow, ridge-till, and no-till tillage methods and continuous corn, corn-soy, and soybean-corn crop rotations three plot replicates for each tillage-rotation combination. All corn crops received $\mathrm{N}$ as anhydrous ammonia. Beginning in 1990, new instrumentation allowed research at Nashua to address management effects on $\mathrm{N}$ transport and leaching in tile flow. From 1993 through 1998, the focus shifted to evaluating different $\mathrm{N}$ management practices used by farmers in the Midwest, including the use of liquid swine 
management, resulting in over 220 peer-reviewed publications, reports, or dissertations. With both a model and an observed dataset, one can test the model against observed results, improve model calibration, and even improve model structure to better represent the processes being simulated.

Soil hydraulic conductivities and soil water retention curves were determined using soil samples collected in 2001 from a nearby field (Ma et al. 2007b). Soil hydraulic properties were estimated and used to calibrate RZWQM, resulting in improved simulations of water relations and $\mathrm{N}$ in tile flow compared to the default soil parameters. Sensitivity analysis showed that the yield and biomass were not sensitive to these hydraulic properties. RZWQM was calibrated using soil data from plot 25 and then used with the same soil and plant parameters, except for lateral hydraulic gradient, to simulate responses for the other 29 plots (Ma et al. 2007a). Ma et al. (2007c) further reported that lateral hydraulic gradients were calibrated for each plot to capture the difference in flow characteristics so that the tile flow, soil water storage, and water table depth simulated values were similar to measured values.

Crop yields were simulated using the generic crop growth component of RZWQM. Saseendran et al. (2007) used a hybrid RZWQM-Decision Support System

Table 1

A general description of the experimental design.

\begin{tabular}{|c|c|c|c|}
\hline Years & Crop rotation & Tillage & $\begin{array}{l}\text { Nitrogen management } \\
\text { on corn }\end{array}$ \\
\hline \multirow[t]{4}{*}{1990 to 1992} & Continuous corn (4) & Moldboard plow (3) & Anhydrous ammonia (12) \\
\hline & Corn-soybean (4) & Chisel plow (3) & \\
\hline & Soybean-corn (4) & Ridge-till (3) & \\
\hline & & No-till (3) & \\
\hline \multirow[t]{3}{*}{1993 to 1998} & Continuous corn (2) & Chisel plow (8) & Swine manure-fall (3) \\
\hline & Corn-soybean (5) & No-till (4) & UAN with LSNT (4) \\
\hline & Soybean-corn (5) & & UAN-spring preplant (5) \\
\hline \multirow[t]{6}{*}{1999 to 2003} & Corn-soybean (6) & Chisel plow (10) & Swine manure-fall (2) \\
\hline & Soybean-corn (6) & No-till (2) & Swine manure-spring (2) \\
\hline & & & Swine manure-fall c + b (2) \\
\hline & & & Swine manure fall + UAN (2) \\
\hline & & & Swine manure fall + LSNT (2) \\
\hline & & & UAN split spring + LCD (2) \\
\hline
\end{tabular}

for Agrotechnology Transfer (DSSAT) model and found the hybrid model did not result in better crop yield estimates than the generic crop component. All recorded management operations were input into the model and used in the RZWQM calibration. Crop yields were overpredicted when UAN and anhydrous ammonia were applied but underpredicted when fall swine manure was applied. The historic trend of yields in
Chickasaw County for the period from 1990 to 2003 using data from the National Agricultural Statistics Service (NASS 2010) was a 3\% annual increase in corn yields and a $1 \%$ increase in soybean yields. Parameterization of RZWQM assumed no time-varying crop parameters affecting yield for either crop. In addition to the 14 years of study, longer term scenarios were also simulated with RZWQM.

\section{Table 2}

A classification of management at Nashua into 16 systems.

\begin{tabular}{ll}
\hline System & Description \\
\hline 1 & No-till, corn-soybean rotation, applying 28\% UAN to corn after LSNT (1993 to1999) \\
2 & No-till, corn-soybean rotation, single 28\% UAN prior to corn planting (1990 to 1999) \\
3 & Chisel plow, corn-soybean rotation, applying 28\% UAN to corn after LSNT (1993 to 2003) \\
4 & Chisel plow, corn-soybean rotation, single 28\% UAN prior to corn planting (1990 to 2003) \\
5 & Chisel plow, corn-soybean rotation, manure application prior to corn (1993 to 2003) \\
6 & Chisel plow, corn-corn rotation, fall manure application (1993 to 1998) \\
7 & Chisel plow, corn-corn rotation, single 28\% UAN prior to planting (1990 to 1998) \\
8 & No-till, corn-corn rotation, single 28\% UAN prior to planting (1990 to 1992) \\
9 & Moldboard plow, corn-corn rotation, single 28\% UAN prior to planting (1990 to 1992) \\
10 & Moldboard plow, corn-soybean rotation, single 28\% UAN prior to corn planting (1990 to 1992) \\
11 & Ridge till, corn-corn rotation, single 28\% UAN prior to planting (1990 to 1992) \\
12 & Ridge till, corn-soybean rotation, single 28\% UAN prior to corn planting (1990 to 1992) \\
13 & Chisel plow, corn-corn rotation, fall manure plus spring 28\% UAN application (1999) \\
14 & Chisel plow, corn-soybean rotation, fall manure applications prior to corn and soybean (2000 to 2003) \\
15 & Chisel plow, corn-soybean rotation, fall manure plus spring 28\% UAN applications for corn (2000 to 2003) \\
16 & No-till, corn-soybean rotation, spring manure application to corn (2000 to 2003) \\
\hline Notes: UAN = urea ammonium nitrate. LSNT = late spring nitrate test.
\end{tabular}

Notes: UAN $=$ urea ammonium nitrate. LSNT $=$ late spring nitrate test. 
Table 3

A more detailed classification of management at Nashua into 35 systems.

\begin{tabular}{|c|c|c|c|c|c|c|}
\hline Treatment & Tillage system & Crop rotation & $\mathrm{N}$ application method & $\mathrm{N}$ rate $\left(\mathrm{kg} \mathrm{ha}^{-1}\right)$ & Year(s) & Plot years \\
\hline 1 & Chisel plow & Corn-corn & Anhydrous & 202 & 1990 to 1992 & 9 \\
\hline 2 & Chisel plow & Corn-corn & SM fall and UAN spring & 184 to 201 & 1999 & 15 \\
\hline 4 & Chisel plow & Corn-corn & SM fall on corn and soybean & 200 to 220 & 2000 & 9 \\
\hline 5 & Chisel plow & Corn-corn & UAN spring preplant & 131 to 138 & 1993 to 1998 & 18 \\
\hline 6 & Chisel plow & Corn-soybean & Anhydrous & 168 & 1990 to 1993 & 9 \\
\hline 8 & Chisel plow & Corn-soybean & SM fall & 80 to 263 & 1994 to 2003 & 9 \\
\hline 9 & Chisel plow & Corn-soybean & SM fall on corn and soybean & 170 to 248 & 2001 to 2003 & 9 \\
\hline 10 & Chisel plow & Corn-soybean & UAN LSNT & 150 to 186 & 1994 to 1999 & 9 \\
\hline 11 & Chisel plow & Corn-soybean & UAN split LCD & 168 to 178 & 2000 to 2003 & 9 \\
\hline 12 & Chisel plow & Corn-soybean & UAN spring preplant & 110 to 168 & 1994 to 2003 & 9 \\
\hline 13 & Chisel plow & Soybean-corn & Anhydrous & 168 & 1990 to 1992 & 15 \\
\hline 17 & Chisel plow & Soybean-corn & SM spring preplant & 206 to 215 & 1999 to 2000 & 18 \\
\hline 18 & Chisel plow & Soybean-corn & UAN LSNT & 78 to 169 & 1993 to 2000 & 18 \\
\hline 19 & Chisel plow & Soybean-corn & UAN split LCD & 168 to 184 & 2001 to 2003 & 18 \\
\hline 20 & Chisel plow & Soybean-corn & UAN spring preplant & 110 to 168 & 1993 to 2003 & 26 \\
\hline 21 & Moldboard plow & Corn-corn & Anhydrous & 202 & 1990 to 1992 & 27 \\
\hline 22 & Moldboard plow & Corn-soybean & Anhydrous & 168 & 1990 to 1992 & 16 \\
\hline 23 & Moldboard plow & Soybean-corn & Anhydrous & 168 & 1990 to 1992 & 9 \\
\hline 24 & No-till & Corn-corn & Anhydrous & 202 & 1990 to 1992 & 18 \\
\hline 25 & No-till & Corn-soybean & Anhydrous & 168 & 1990 to 1993 & 30 \\
\hline 26 & No-till & Corn-soybean & SM spring preplant & 122 to 235 & 2000 to 2003 & 33 \\
\hline 34 & Ridge till & Corn-soybean & Anhydrous & 168 & 1990 to 1992 & 9 \\
\hline 35 & Ridge till & Soybean-corn & Anhydrous & 168 & 1990 to 1992 & 6 \\
\hline
\end{tabular}

Notes: The range of nitrogen $(\mathrm{N})$ rates applied only to corn unless otherwise noted. $\mathrm{SM}=$ swine manure. UAN = urea ammonium nitrate. LSNT = late spring $N$ test. $L C D=$ localized compaction and doming.

Table 4

Management practices recorded for each plot and year.

\begin{tabular}{|c|c|c|c|}
\hline Crop & Tillage & Nitrogen fertilizer & Herbicide \\
\hline Rotation & Method & Preplant type & Formula(s) \\
\hline Variety & Primary tillage date & Preplant rate & Method(s) \\
\hline Planting date & Secondary tillage date & Preplant method & Active ingredient(s) \\
\hline Seeds per acre & Row cultivation date(s) & Preplant application date & Active ingredient rate(s) \\
\hline Emergence date & & Postplant type & Application date(s) \\
\hline \multirow[t]{3}{*}{ Harvest date } & & Postplant rate & \\
\hline & & Postplant method & \\
\hline & & Postplant application date & \\
\hline
\end{tabular}


Of the 36 plots, 6 were not simulated (plots 8, 17, 20,27, 30, and 31) because of very high or low drainage, but there were still at least two replicates for each treatment (Ma et al. 2007a). A number of events occurred in specific years that could complicate efforts to simulate management effects at Nashua, such as drought in 1988 and 1989 resulting in a $\mathrm{NO}_{3}$ buildup in the soil, floods in 1993, hail damage to crops in 1995, etc. Table 2 of Malone et al. (2007b) lists the plots and years when the measured data at Nashua may be difficult to integrate in empirical or process-based simulation models.

Economic Budget Preparation. The online budget development tool EconDocs was used to create crop budgets. EconDocs has been superseded by a newer tool named DevTreks (2012), designed specifically for social budgeting or the shared creation of budgets on the Internet. DevTreks implements the American Agricultural Economics Association recommendations for estimating agricultural costs and returns (Hallam et al. 1999) and includes extensive features for sharing, manipulating, and analyzing budgets. We created crop operating budgets for all 504 crop years at Nashua between 1990 and 2003 based on the equipment in use at Nashua in 2003, which was smaller than equipment used on large commercial farms. National prices for most inputs in each year were taken from the National Agricultural Statistics Service (USDA National Agricultural Statistics Service 2003). Expenses were calculated for operating costs, such as materials, fuel, and repairs, as well as allocated overhead costs, like machinery capital recovery costs. Net income was derived by subtracting operating and allocated overhead costs from total revenues (output yield $\times$ output price). These budgets are similar to published budgets for Iowa, except the prices are for different time periods, there is some variation in technology, and there is no charge for land (Iowa State University 2006). These budgets reflect the cost of production at Nashua for the 1990 to 2003 study but do not reflect the increases in input and output prices seen since 2003 .

\section{Results and Discussion}

Operations. A detailed record of all operations applied to the 504 plot-years is available (at http://apps.tucson.ars.ag.gov/nashua) as a Microsoft Excel Workbook (mention of trade names or commercial products is solely

\section{Figure 2}

Root Zone Water Quality Model simulated vs. measured nitrogen (N) loadings. Gray, open circles are annual values, and black, filled circles are treatment means.

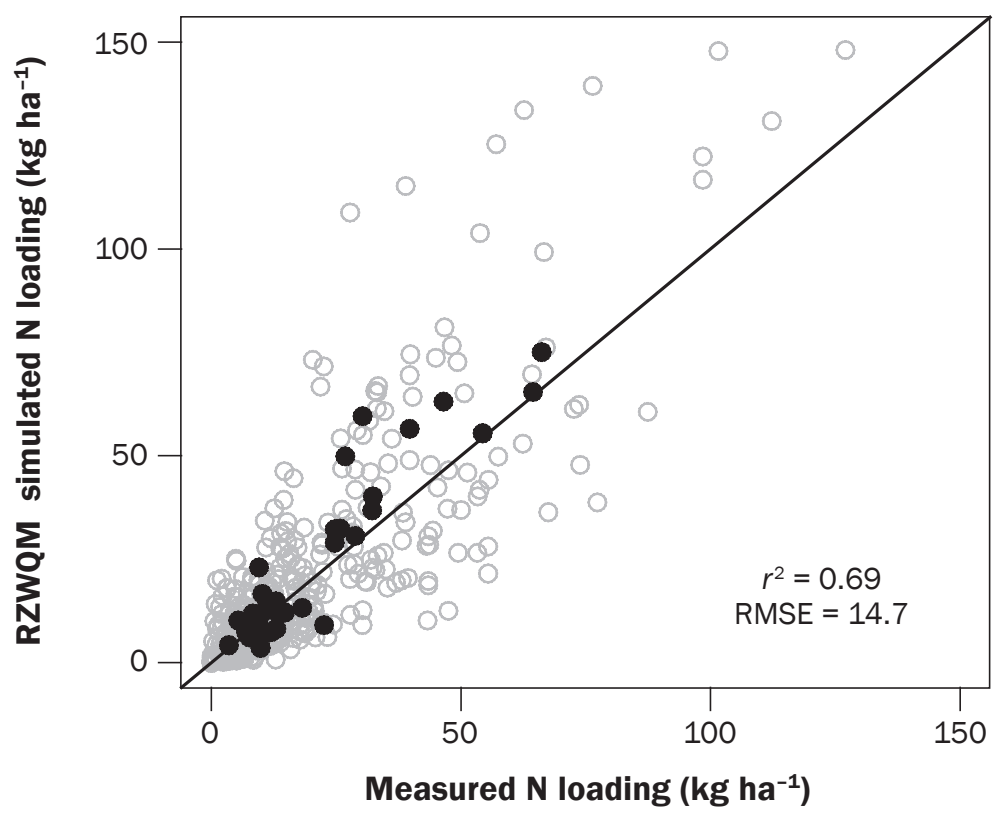

for the purpose of providing specific information and does not imply recommendation or endorsement by the USDA). Individual worksheets contain:

- Treatments by plot and year

- Plots by treatment and year

- Treatment names

- Measured outputs by plot

- Mean yields and loading by treatment

- Field operations for $\mathrm{N}$ fertilizer and herbicide

- P and potassium (K) application amounts

- Pesticide application amounts

Database of Measured and Simulated Results. A graphical introduction to the observed record was made by plotting effects of the 16 treatments listed in table 2 on $\mathrm{N}$ loading and crop yield (USDA ARS 2011a). Summary plots show the mean effect of each treatment by rotation, tillage, and $\mathrm{N}$ application method. The effects are also displayed for each plot and year.

Similarly, a graphical comparison of the measured and RZWQM-simulated results on tile flow, $\mathrm{N}$ concentration, $\mathrm{N}$ loading, and crop yields is available (USDA ARS 2011b). Summary plots of the general relationships on all 420 simulated plot-years are compared with the measured, along with $r^{2}$ and Nash Sutcliffe values. Included are a series of graphics showing measured vs. simulated results for corn yield, soybean yield, tile flow, $\mathrm{N}$ concentration, $\mathrm{N}$ loading by plot, by year, and by treatment (table 3 ). From the graphical comparison, figures 2 and 3 summarize the RZWQM simulations compared to the measured values. In figure 2 , individual plot years are plotted as gray open circles and the means for each of the 35 treatments appear as filled black circles. In figure 3 , it is clear that soybean yield simulation tends to be more accurate than corn.

The measured and simulated datasets can be explored interactively with charting functionality using a Microsoft Access 2007 database. After a treatment or treatments are selected, the user defines the crop (corn or soybean), specifies whether measured or simulated data are desired, and identifies if a comparison of simulated vs. measured $\mathrm{N}$ loading, tile flow, or yield is needed by treatment or by year. The user is told which years meet all criteria and a chart opens to display the information, as shown in figure 4 . In the figure, the measured and simulated mean yields and ranges are similar. For both treatments, the crop planted in an even year appears to have a higher mean yield: corn in Treatment 8 and soybeans in Treatment 15 .

There is a more detailed query builder interface that allows the user to select individual years and plots; filter for specific tillage, $\mathrm{N}$ management, crop rotation, and crop; then define the output variables of interest. In the last step, measured or sim- 


\section{Figure 3}

Root Zone Water Quality Model (RZWQM) simulated vs. measured crop yields. Gray symbols are annual values, and black symbols are treatment means.

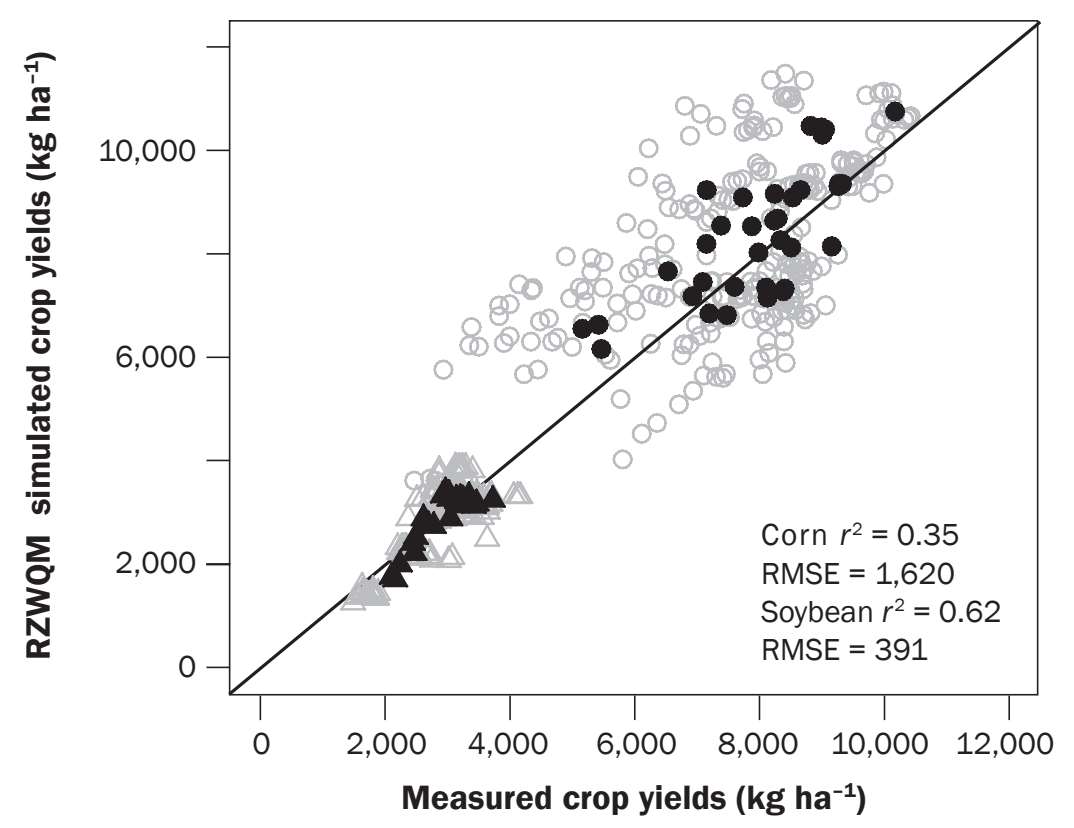

\section{Legend}

\section{- Corn Soybean}

ulated data are specified. Charts can be provided either by plot or by date. The data can be exported as a Microsoft Excel work- book from both the query builder and the summary interface. Users that do not have Microsoft Access can download a summary
Excel Workbook that lists simulated and measured values of crop yield, tile flow, $\mathrm{N}$ concentration, and $\mathrm{N}$ loading.

Root Zone Water Quality Model Input Files. The final RZWQM input files for each treatment are also available for each of the 30 simulated plots in separate folders. The RZWQM interface manages model parameterization and analysis of results. Changes to model parameters should only be made through the interface, instead of directly editing input files. For clarity, a brief description of some of the files needed to run RZWQM is provided.The file project.rzp lists the available parameterized simulations. For Nashua, there are 30 projects, each corresponding to the 14 years within one of the 30 simulated plots. Within each plot's folder, the ipnames.dat file lists the input files needed for that project. The file rzwqm.dat contains a number of inputs including soil horizons and soil chemistry information. The rzinit. dat file is used to initialize the state variables. Plant growth information is contained in the plgen.dat file. Meteorological information is in a separate subfolder containing files with the .met and .brk extensions that describe the meteorology and breakpoint precipitation inputs and sno files with snowfall data. The cntrl.dat defines the desired model output. Lastly, the file expdata.dat contains

\section{Figure 4}

Chart from database comparing (a) measured vs. (b) simulated crop yield for two treatments (8 and 15 ).

(a)

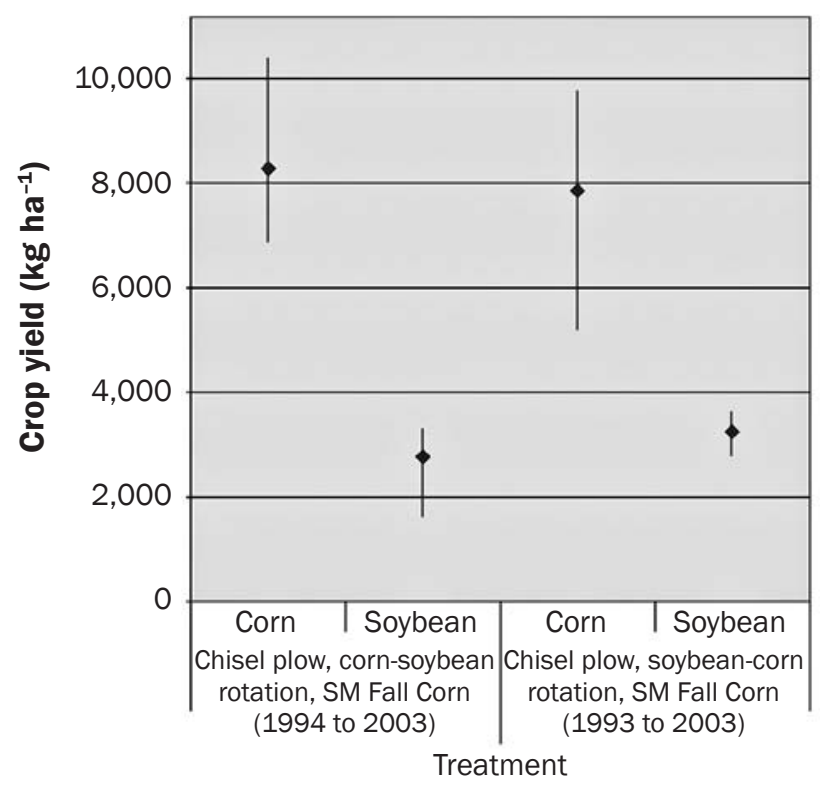

(b)

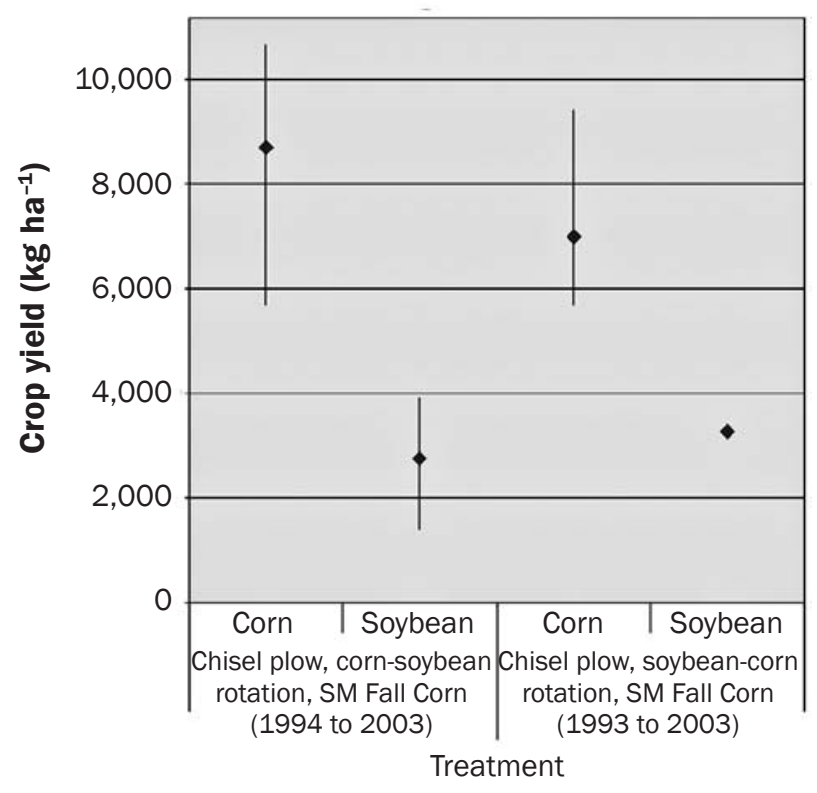




\section{Figure 5}

(a) Measured and (b) simulated net returns vs. nitrogen $(\mathrm{N})$ loadings. Gray circles are annual values; black, open circles are treatment means from 1990 to 1992; and black, filled circles are treatment means from 1993 to 2003.

(a)

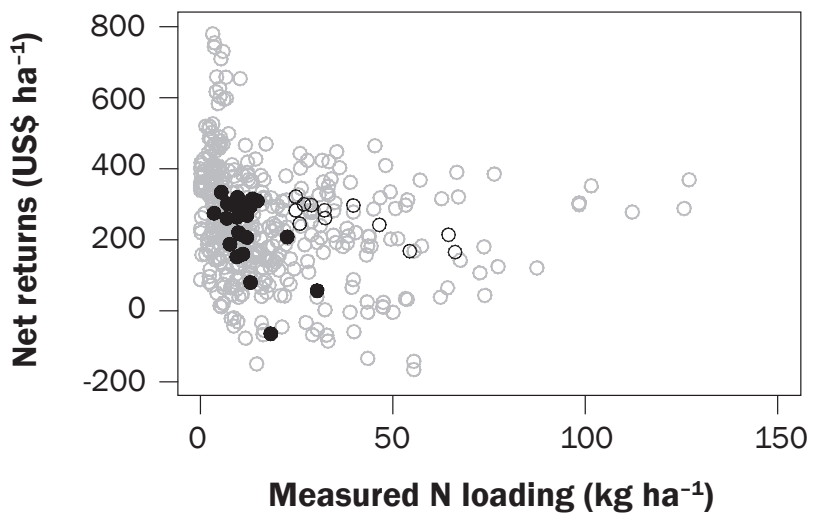

(b)

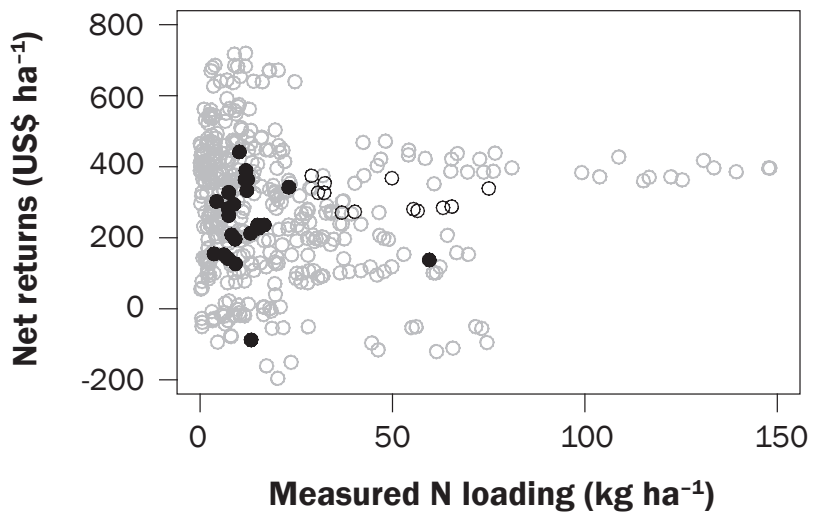

measured data from each plot for comparison with the simulated data.

Budgets. An Excel Workbook summarizing the simulated and measured budgets is available for download. More detailed analysis of the budgets can be done when the DevTreks software comes online. Figures $5 \mathrm{a}$ and $5 \mathrm{~b}$ show the measured and simulated trade-offs between net returns and $\mathrm{N}$ loading, again with individual years in gray open circles and the means of each treatment in filled circles. As farmers are interested in maximizing their net return while society is interested in minimizing the $\mathrm{N}$ loading, the most desirable treatments are in the upper left quadrant. Because the treatment means are averaged across different years, firm conclusions are difficult to draw. However, there appears to be some scope for reducing $\mathrm{N}$ loading and maintaining high net returns, depending on the initial management system, as there are a number of treatments with both high returns and low $\mathrm{N}$ loadings. The management systems studied after 1992 all tend to have lower mean $\mathrm{N}$ loading rates in part due to the dry conditions in 1988 and 1989 that led to high levels of $\mathrm{N}$ in the soil. Input costs and crop prices have since risen significantly, so identifying preferred management systems would require specifying expected input costs and output prices.

Fathelrahman et al. (2011a, 2011b) used the Nashua economic data to compare risk analysis methods, such as stochastic dominance and stochastic efficiency, with respect to a function. The rankings were nonconclusive since the results depended on the economic value of interest and the level of risk aversion.

In addition to the data listed above, related Web sites and a list of publications describing research on the experimental plots at Nashua can be found on the Web site. Contact email addresses for more information are also provided.

Precipitation Effects. Randall and Iragavarapu (1995) in a study in Waseca, Minnesota, and Jaynes et al. (1999) in a study of Walnut Creek, near Ames, Iowa, found that $\mathrm{N}$ losses are highly dependent on precipitation, particularly in the growing season. Hatfield et al. (2009) reported that annual $\mathrm{NO}_{3}-\mathrm{N}$ loads in the Raccoon River were significantly correlated with precipitation in the first five months of the year. Precipitation is also linked to $\mathrm{N}$ loading at Nashua, as shown in figure 6 . The annual precipitation was significantly correlated with measured annual $\mathrm{N}$ loading $(r=0.54)$, and the second quarter precipitation (April through June) significantly correlated with the second quarter measured $\mathrm{N}$ loading $(r=0.51)$. To the extent that precipitation determines $\mathrm{N}$ loading, there is less scope for management to have an effect on $\mathrm{N}$ loads entering tile flow.

\section{Management Impacts on Nitrogen} Loading. As the purpose of this paper is to present the Nashua dataset, detailed discussion of the results presented in the special issue will not be repeated here. The preface to the special issue by Ahuja and Hatfield (2007) introduces the eight papers and summarizes the major findings. The following salient question is not addressed directly by Ahuja and Hatfield: What do the measured and simulated results in the dataset imply about the management changes needed at Nashua to reduce $\mathrm{N}$ loading delivered to the Gulf by $45 \%$ ?

Specific reductions from several management systems are reported in the special issue.
Malone et al. (2007b) reported that, according to RZWQM, manure resulted in $7 \mathrm{~kg} \mathrm{~N} \mathrm{ha}^{-1}$ $\left(6.2 \mathrm{lb} \mathrm{N} \mathrm{ac}^{-1}\right)$ less $\mathrm{NO}_{3}$ leaching than UAN. This was from a base of $36.8 \mathrm{~kg} \mathrm{~N} \mathrm{ha}^{-1}(32.8$ $\mathrm{lb} \mathrm{N} \mathrm{ac}{ }^{-1}$ ), so the percentage reduction was 19\%. Similarly, spring application of manure resulted in less $\mathrm{NO}_{3}$ loading than fall application, $8 \mathrm{~kg} \mathrm{~N} \mathrm{ha}^{-1}\left(7.1 \mathrm{lb} \mathrm{N} \mathrm{ac}^{-1}\right)$ from a base of $35.8 \mathrm{~kg} \mathrm{~N} \mathrm{ha}^{-1}\left(31.9 \mathrm{lb} \mathrm{N} \mathrm{ac}^{-1}\right)$ or $22 \%$.

The use of RZWQM also allowed study of several management practices that were not addressed in the Nashua experimental design. Malone et al. (2007a) simulated a winter cover crop using the "quickplant" routine in RZWQM. A simulation of 150 $\mathrm{kg} \mathrm{N} \mathrm{ha}{ }^{-1}\left(133.8 \mathrm{lb} \mathrm{N} \mathrm{ac}^{-1}\right)$ applied as UAN on a chisel-plow, corn-soybean rotation for the period from 1961 to 2003 resulted in $\mathrm{N}$ loading of $16 \mathrm{~kg} \mathrm{~N} \mathrm{ha}^{-1}\left(14.3 \mathrm{lb} \mathrm{N} \mathrm{ac}^{-1}\right)$. Adding a winter wheat cover crop reduced average $\mathrm{N}$ loading to $11.1 \mathrm{~kg} \mathrm{~N} \mathrm{ha}^{-1}(9.9 \mathrm{lb}$ $\mathrm{N} \mathrm{ac}{ }^{-1}$ ), or a $31 \%$ reduction. Similarly, $\mathrm{Ma}$ et al. (2007b) found that a simulation comparison for 6 management systems with free drainage compared to six with controlled drainage from 1979 to 2002 resulted in a decrease in $\mathrm{N}$ loading of $29 \%$ from $17.8 \mathrm{~kg}$ $\mathrm{ha}^{-1}\left(15.9 \mathrm{lb} \mathrm{ac}^{-1}\right)$, although $\mathrm{N}$ losses in lateral flow increased by $17 \%$. These last two examples illustrate the potential for using the Nashua field data and RZWQM parameterization to make a preliminary assessment of the expected magnitude of management effects for practices that have not been studied at Nashua.

Long-Term Simulation. A short example shows one type of analysis that can be undertaken given the Nashua dataset: to understand the magnitude of the management change required to meet a $45 \%$ reduction in $\mathrm{N}$ deliv- 


\section{Figure 6}

(a) Measured and (c) simulated annual precipitation effect on nitrogen ( $N$ ) loading and (b) measured and (d) simulated second quarter (April to June) precipitation effect on $\mathrm{N}$ loading.

(a)

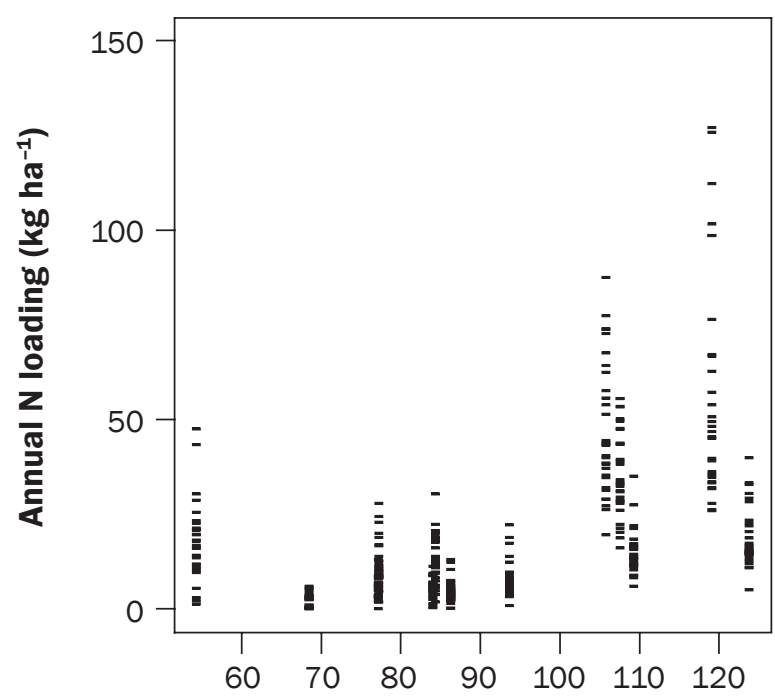

(c)

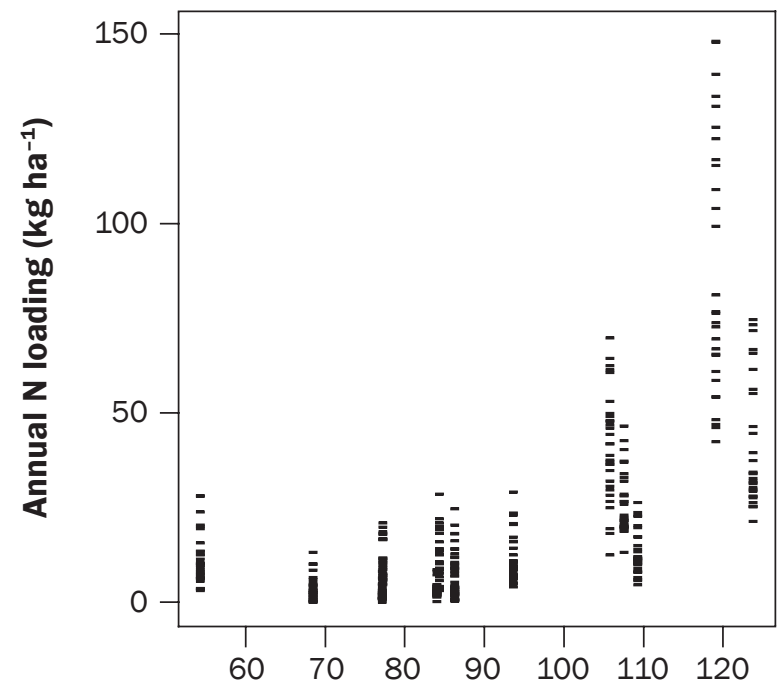

(b)

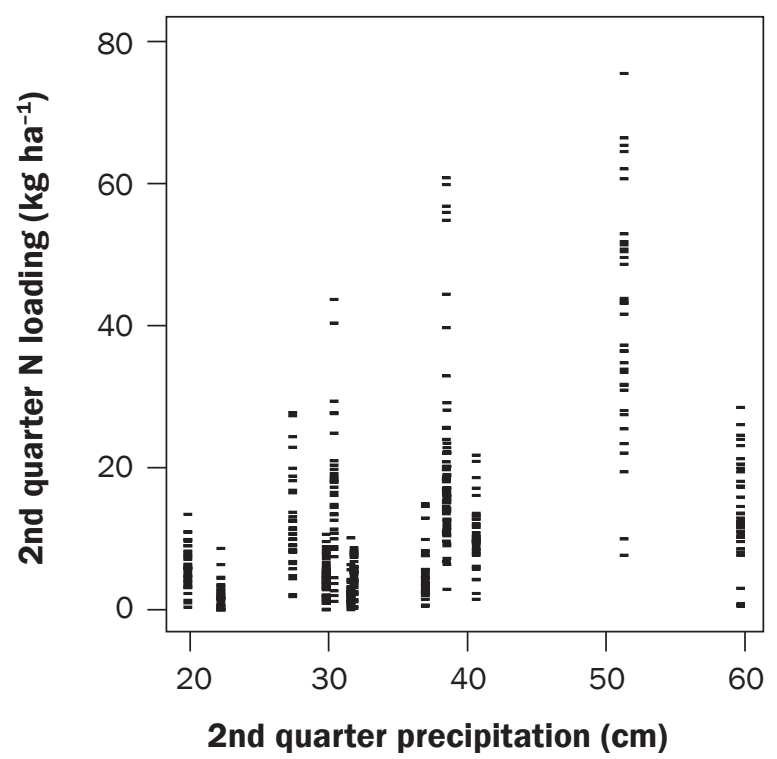

(d)

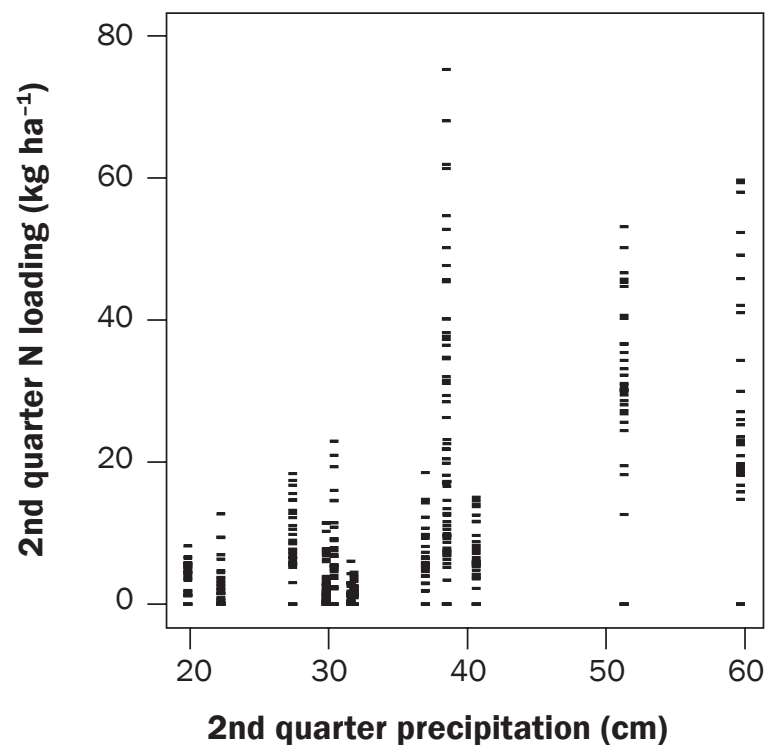

ered to tile system. The difficulty in reducing $\mathrm{N}$ loading will depend on a field's initial level of $\mathrm{N}$ loading. To explore the effect of the initial starting point, 18 management systems were defined and simulated in 3 sets of 6 (table 5) from 1974 to 2003. Two tillage systems (no-till and chisel-plow) were used with three rotations (corn-corn, corn-soybean, and soybean-corn), all with $\mathrm{N}$ applied in the spring as the set of "Spring" management systems. Another set of 6 management systems with more generous application of
$\mathrm{N}$ applied in the fall is labeled "High Fall," and a third set with low $\mathrm{N}$ application rates in the spring is labeled "Low Spring". To reduce uncertainty, the management systems are averaged for the individual management systems and grouped by rotation. As can be seen in figure 7 , corn yields plotted against $\mathrm{N}$ loadings form a roughly horizontal line, indicating similar corn yields with differences in $\mathrm{N}$ loading for both continuous corn and corn with soybeans. A reduction of $45 \%$ in $\mathrm{N}$ loading from the mean of each set of management systems is indicated on the plots. As would be expected, producers growing continuous corn, particularly with fall $\mathrm{N}$ application, have the greatest scope for reducing $\mathrm{N}$ loading.

A producer starting with the High Fall set of practices could reduce $\mathrm{N}$ loading by $45 \%$ by reducing $N$ application and/or timing. However, it is not realistic for all farms to apply $\mathrm{N}$ on all their fields in the spring, particularly those farms that need to dispose of swine manure. Similarly, a hypothetical 


\begin{tabular}{|c|c|c|c|c|c|c|}
\hline $\begin{array}{l}\text { Nashua } \\
\text { treatments }\end{array}$ & Number & Tillage & Rotation & $\begin{array}{l}\text { Nitrogen } \\
\text { amount } \\
\text { (kg N ha-1) }\end{array}$ & $\begin{array}{l}\text { Nitrogen } \\
\text { type }\end{array}$ & Season \\
\hline \multirow[t]{6}{*}{ Spring } & 1 & $\mathrm{CP}$ & $\mathrm{CC}$ & 150 & UAN & Spring \\
\hline & 2 & $\mathrm{CP}$ & $\mathrm{CS}$ & 150 & UAN & Spring \\
\hline & 3 & $\mathrm{CP}$ & SC & 150 & UAN & Spring \\
\hline & 4 & NT & $\mathrm{CC}$ & 150 & UAN & Spring \\
\hline & 5 & NT & $\mathrm{CS}$ & 150 & UAN & Spring \\
\hline & 6 & NT & SC & 150 & UAN & Spring \\
\hline \multirow[t]{6}{*}{ Low spring } & 7 & $\mathrm{CP}$ & $\mathrm{CC}$ & 135 & UAN & Spring \\
\hline & 8 & NT & $\mathrm{CC}$ & 135 & UAN & Spring \\
\hline & 9 & $\mathrm{CP}$ & $\mathrm{CS}$ & 110 & UAN & Spring \\
\hline & 10 & NT & CS & 110 & UAN & Spring \\
\hline & 11 & $\mathrm{CP}$ & SC & 110 & UAN & Spring \\
\hline & 12 & NT & SC & 110 & UAN & Spring \\
\hline \multirow[t]{6}{*}{ High fall } & 13 & $\mathrm{CP}$ & $\mathrm{CC}$ & 200 & Anhydrous & Fall \\
\hline & 14 & NT & $\mathrm{CC}$ & 200 & Anhydrous & Fall \\
\hline & 15 & $\mathrm{CP}$ & $\mathrm{CS}$ & 168 & Anhydrous & Fall \\
\hline & 16 & NT & $\mathrm{CS}$ & 168 & Anhydrous & Fall \\
\hline & 17 & $\mathrm{CP}$ & SC & 168 & Anhydrous & Fall \\
\hline & 18 & NT & SC & 168 & Anhydrous & Fall \\
\hline
\end{tabular}

Notes: Spring = all nitrogen $(\mathrm{N})$ applied in the spring. Low spring = low $\mathrm{N}$ application rates in the spring. High fall $=$ high rates of $\mathrm{N}$ applied in the fall. $\mathrm{CP}=$ chisel plow. $\mathrm{NT}=$ no-till. $\mathrm{CC}=$ corn-corn. $\mathrm{CS}=$ corn-soybean. $\mathrm{SC}=$ soybean - corn $. \mathrm{SM}=$ swine manure. $\mathrm{UAN}=$ urea ammonium nitrate.

farmer at Nashua using the Spring set of systems would have to reduce $\mathrm{N}$ loadings from the current $19.6 \mathrm{~kg} \mathrm{~N} \mathrm{ha}{ }^{-1}\left(17.5 \mathrm{lb} \mathrm{N} \mathrm{ac}^{-1}\right)$ to roughly $10.8 \mathrm{~kg} \mathrm{~N} \mathrm{ha}^{-1}\left(9.6 \mathrm{lb} \mathrm{N} \mathrm{ac}^{-1}\right)$, which is lower than the Low Spring set of systems. This can be thought of as removing the insurance level of fertilizer. Corn yields on the Low Spring systems are slightly lower than for the Spring set, although the difference is not statistically significant (Wilcoxon Rank Sum Test $p$-value $=0.051)$. Farmers would be reluctant to trust simulation results at low rates of $\mathrm{N}$ application as corn comes off of its yield plateau. Reducing $\mathrm{N}$ loading by $45 \%$ would require more than simple changes in $\mathrm{N}$ application methods rates and timing and would require additional, more costly methods, such as switching to manure if available, cover crops, controlled drainage, or rotations that include hay or small grains. This finding echoes the conclusion of Dinnes et al. (2002) that "several different management practices will be required to ensure that surface and groundwater resources achieve a quality acceptable to society as a whole."

We should note that there is some question about how the $\mathrm{N}$ reduction goals in the Gulf should be interpreted for $\mathrm{N}$ entering tile drains in northern Iowa. Some authors (Doering et al. 1999) have assumed a con- stant in-stream denitrification loss, so that a reduction in $\mathrm{N}$ loading will lead to a proportional reduction in $\mathrm{N}$ delivered to the Gulf of Mexico. McIssac et al. (2001) point out that in-stream denitrification rates vary depending on rainfall rates and local conditions, although they do not specifically address tile-drained agriculture. Alexander et al. (2000) estimate that the median amount of $\mathrm{N}$ in streamflow delivered to the Gulf of Mexico from the Upper Mississippi Basin is $61 \%$, with over $90 \%$ delivered from those watersheds adjacent to the Mississippi River so that $\mathrm{NO}_{3}$ is conservatively transported once in large river systems.

\section{Summary and Conclusions}

The Nashua dataset presented here is limited to the 14-year study period, the conditions at Nashua, and the management systems in the experimental design. Ideally, this information would provide a foundation for field-scale decision making. An analysis of how the Nashua dataset could be applied to a larger area is provided in Heilman et al. (2012). The RZWQM model was parameterized with the Nashua dataset and extended by a consistent and longer period of climatic data to facilitate consideration of an expanded set of management alternatives and economic-en- vironmental tradeoffs assessed in a decision support system.

Clearly, long-term intensively monitored datasets like Nashua can provide an empirical foundation to more systematically address water quality problems in the Midwest. Nevertheless, the interaction of time-specific and site-specific measurements creates a reluctance to generalize for other times, places, and combinations of management practices. Process-based simulation models like RZWQM can help in understanding the interaction of components of the agricultural system and can extend those results to times, fields, and management systems where measurements have not been made. However, parameterizing process-based models is complex and time consuming.

We do not have an information system that integrates expert opinion, intensively monitored data, and simulation models to deliver site-specific information within a decision-making framework incorporating appropriate economic incentives. Heilman et al. (2002) proposed collaboration through models and a database. Malone et al. (2007b) recommend an empirical metamodel to simplify and synthesize results from process-based models. Such a metamodel would be particularly useful if data collected for precision agriculture relating $\mathrm{N}$ application to particular soil series and the resulting yields are made available to the modeler, as well as watershed monitoring information. Another possibility is an N Index model (Delgado et al. 2010), although the model would have to be specific to tile-drained conditions.

Addressing hypoxia in the Gulf of Mexico will require a substantial effort, including additional research on the site-specific $\mathrm{N}$ loading and net return tradeoffs of commonly used management systems in tile-drained agriculture, in addition to controlling other sources of $\mathrm{N}$ and P.The field is the agricultural management unit that determines if $\mathrm{NO}_{3}-\mathrm{N}$ will enter the tile drains and ultimately the stream system. By providing access to the Nashua dataset, we hope other researchers can take advantage of this rich dataset to better understand management effects on $\mathrm{N}$ and crop yields and, ultimately, reduce downstream environmental problems.

\section{Acknowledgements}

We would like to thank Carl Pederson and Ken Pecinovsky of Iowa State University, Reggie Voss of Iowa Extension (retired), Kathy Woodard and Caitlin Hall of the University 


\section{Figure 7}

Long term simulations showing the means of six simulations for 30 years each and an assumed reduction in nitrogen $(\mathrm{N})$ loading of $45 \%$ split between (a) corn with soybean rotations and (b) continuous corn.

(a)

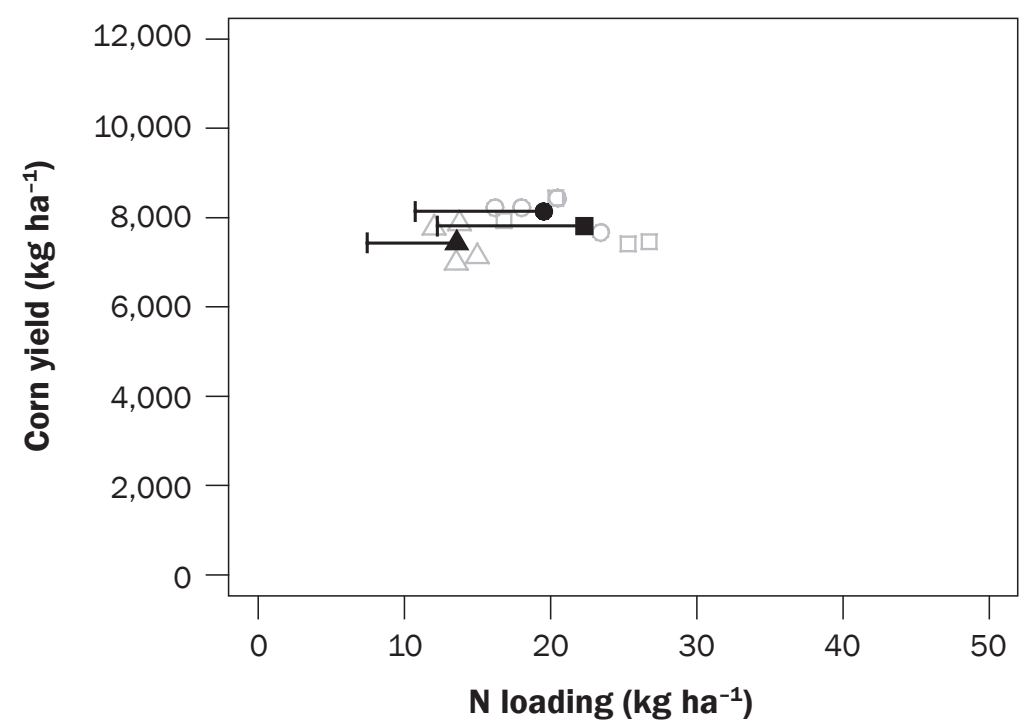

(b)

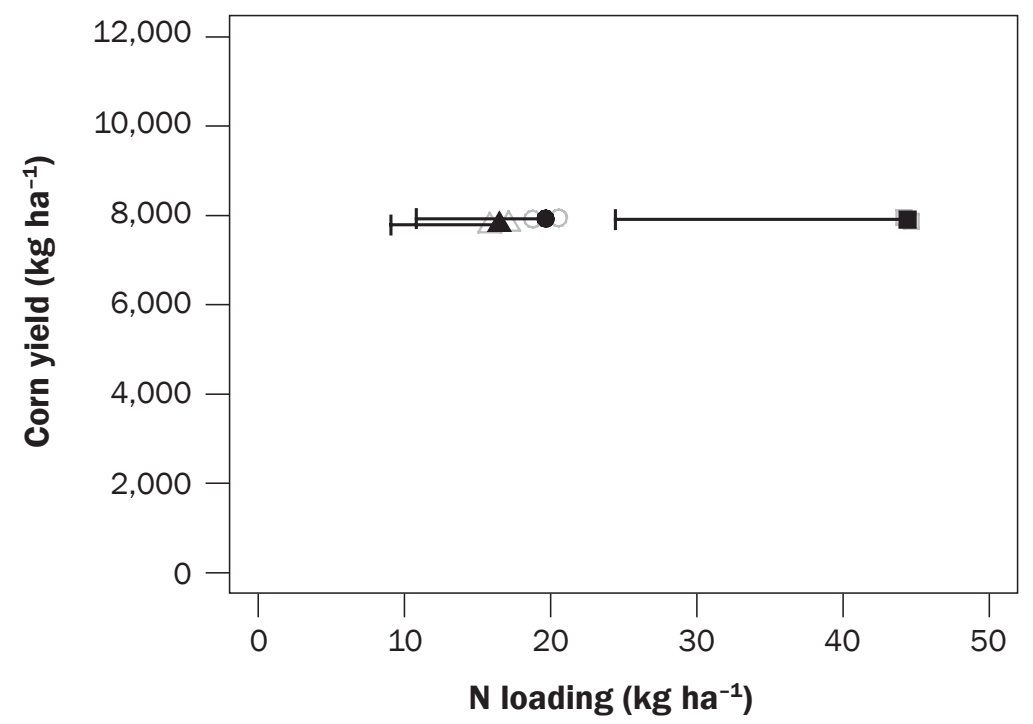

Legend

- Spring

A Low spring

High fall

of Arizona, Jim Ayen, Alan Lauver, Barbara Stewart, Steve Brinkman, and Hal Cosby of the NRCS in Iowa, Terry Meade, Bob Jacquis, and Gerardo Armendariz of the Agricultural Research Service.

\section{References}

Ahuja, L.R., and J.L. Hatfield (eds). 2007. Integrating soil and crop research with system models in the Midwest USA. Geoderma 140(3):217-322.
Ahuja, L.R., and L.J. Hatfield. 2007. Integrating soil and crop research with system models in the Midwest USA: Purpose and overview of the special issue. Geoderma 140(3):217-222.

Ahuja, L.R., K.W. Rojas, J.D. Hanson, M.J. Shaffer, and L. Ma, eds. 2000. The Root Zone Water Quality Model. Highlands Ranch, CO:Water Resources Publications LLC.

Alexander, R.B., R.A. Smith, and G.E. Schwarz. 2000. Effect of stream channel size on the delivery of nitrogen to the Gulf of Mexico (Supplementary Material). Nature 403:758-761.

Bakhsh, A., R.S. Kanwar, and R.W. Malone. 2007. Role of landscape and hydrologic attributes in developing and interpreting yield clusters. Geoderma 140(3):235-246.

Delgado, J.A., P.M. Gagliardi, M.J. Shaffer, H. Cover, and E. Hesketh. 2010. Chapter 14. New tools to assess nitrogen management for conservation of our biosphere. In Advances in Nitrogen Management for Water Quality. J.A. Delgado and R.F. Follett, eds, 373-409. Ankeny, IA: Soil and Water Conservation Society.

DevTreks. Social budgeting that improves lives and livelihoods. http://devtreks.org/home.html.

Dinnes, D.L., D.L. Karlen, D.B. Jaynes, T.C. Kaspar, J.L. Hatfield, T.S. Colvin, and C.A. Cambardella. 2002. Review and interpretation: Nitrogen management strategies to reduce nitrate leaching in tile-drained Midwestern soils. Agronomy Journal 94:153-171.

Doering, O.C., F. Diaz Hermelo, C. Howard, R. Heimlich, F. Hitzhuzen, R. Kazmierczak, J. Lee, L. Libby, W. Milon, T. Prato, and M. Ribaudo. 1999. Evaluation of the economic costs and benefits of methods for reducing nutrient loads to the Gulf of Mexico, National Oceanic and Atmospheric Administration Coastal Ocean Program Decision Analysis Series, No. 20. Silver Spring, MD: National Oceanic and Atmospheric Administration Coastal Ocean Program.

Fathelrahman, E.M., J.C. Ascough II, D.L. Hoag, R.W. Malone, P. Heilman, L. Wiles, and R.S. Kanwar. 2011a. An economic and stochastic efficiency comparison of tillage systems in corn and soybean under risk. Experimental Agriculture 47(1):111-136.

Fathelrahman, E.M., J.C. Ascough II, D.L. Hoag, R.W. Malone, P. Heilman, L. Wiles, and R.S. Kanwar. 2011b. Continum of risk analysis methods to assess tillage system sustainability at the experimental plot level. Sustainability 3(7):1035-1063.

Hallam, A., V.E. Eidman, M. Morehart, and K. Klonsky, eds. 1999. Commodity Costs and Returns Estimation Handbook: A Report of the AAEA Task Force on Commodity Costs and Returns, Staff General Research Papers 1315. Ames, IA: Iowa State University, Department of Economics.

Hatfield, J.L., L.D. McMullen, and C.S. Jones. 2009. Nitrate-nitrogen patterns in the Raccoon River Basin related to agricultural practices. Journal of Soil and Water Conservation 64(3):190:199, doi:10.2489/ jswc.64.3.190.

Heilman, P., J.L. Hatfield, K. Rojas, L. Ma, J. Huddleston, L.R. Ahuja, and M.Adkins. 2002. How good is good enough? What information is needed for agricultural water quality planning and how can it be provided affordably? Journal of Soil and Water Conservation 57(4)98-105.

Heilman, P., R.W. Malone, L. Ma, J.L. Hatfield, L. Ahuja, K. Boyle, and R.S. Kanwar. 2012. Extending results from agricultural fields with intensively monitored data 
to surrounding areas for water quality management. Agricultural Systems 106:59-71.

Iowa State University. 2006. Estimated Costs of Crop Production in Iowa. Ames, IA: Iowa State University. http://www.econ.iastate.edu/faculty/duffy/pages/ fm1712_2006.pdf.

Jaynes, D.B., J.L. Hatfield, and D.W. Meek. 1999. Water quality in Walnut Creek Watershed: Herbicides and nitrate in surface waters. Journal of Environmental Quality 28:45-59.

Kanwar, R.S. 2006. Effects of cropping systems on $\mathrm{NO}_{3} \mathrm{~N}$ losses to tile drain. Journal of American Water Resources Association 42(6):1493-1501.

Ma, L., R. W. Malone, P. Heilman, L.R. Ahuja, T. Meade, S.A. Saseendran, J.C. Ascough II, and R.S. Kanwar. 2007c. Sensitivity of tile drainage flow and crop yield on measured and calibrated soil hydraulic properties. Geoderma 140(3):284-296.

Ma, L., R.W. Malone, P. Heilman, D.B. Jaynes, L.R. Ahuja, S.A. Saseendran, R.S. Kanwar, and J.C. Ascough, II. 2007b. RZWQM Simulated effects of crop rotation, tillage, and controlled drainage on crop yield and nitrate-N loss in drain flow. Geoderma 140(3):260-271.

Ma, L., R.W. Malone, P. Heilman, D.L. Karlen, R.S. Kanwar, C.A. Cambardella, S.A. Saseendran, and L.R. Ahuja. 2007a. RZWQM simulation of long-term crop production, water and nitrogen balances in northeast Iowa. Geoderma 140(3):247-259.

Malone, R.W., L. Ma, P. Heilman, D.L. Karlen, R.S. Kanwar, and J.L. Hatfield. 2007a. Simulated N management effects on corn yield and tile-drainage nitrate loss. Geoderma 140(3):272-283.

Malone, R.W., L. Ma, D.L. Karlen, T. Meade, D. Meek, P. Heilman, R.S. Kanwar, and J.L. Hatfield. 2007b. Empirical analysis and prediction of nitrate loading and crop yield for corn-soybean rotations. Geoderma 140(3):223-234.

Malone, R.W., D.W Meek, J.L. Hatfield, M.E. Mann, R.J. Jacquis, and L. Ma. 2009. Quasi-biennial corn yield cycles in Iowa. Agricultural and Forest Meteorology 149(6\&7):1087-1094.

McIssac, G.F., M.B. David, G.Z. Gertner, and D.A. Goolsby. 2001. Nitrate flux in the Mississippi River. Nature 414:166-167.

Mississippi River/Gulf of Mexico Watershed Nutrient Task Force. 2008. Gulf Hypoxia Action Plan 2008 for reducing, mitigating, and controlling hypoxia in the northern Gulf of Mexico and improving water quality in the Mississippi River Basin. Washington, DC: US Environmental Protection Agency Office of Wetlands, Oceans, and Watersheds.

NASS (National Agricultural Statistics Service). 2010. Quick Stats. http://www.nass.usda.gov/Data_and_Statistics/ Quick_Stats/index.asp.

Natural Resources Conservation Service. 2012. http://soils.usda.gov/technical/classification/osd/ index.html.
Randall, G.W., and T.K. Iragavarapu. 1995. Impact of longterm tillage systems for continuous corn on nitrate leaching to tile drainage. Journal of Environmental Quality 24:360-366.

Sadler, E.J.,J.L.Steiner,J.Chen, G.J.Wilson, J.D. Ross, T. Oster, D.E. James, B.C. Vandenberg, and J.L. Hatfield. 2008. STEWARDS watershed data system: data development, user interaction, and operations management. Journal of Soil and Water Conservation 63(6):577-589.

Saseendran, S.A., L. Ma, R.W.Malone, P.Heilman, L.R.Ahuja, R.S. Kanwar, D.L. Karlen, and G. Hoogenboom. 2007. Simulating management effects on crop production, tile drainage, and water quality using RZWQM-DSSAT. Geoderma 140(3):297-309.

Steiner, J.L., E.J. Sadler, J.L. Hatfield, G.J. Wilson, D.E. James, B.C. Vandenberg, J.D. Ross, T. Oster, and K.L. Cole. 2009a. Data management to enhance long-term watershed research capacity: context and STEWARDS case study. Journal of Ecohydrology 2:391-398.

Steiner, J.L., E.J. Sadler, G.J. Wilson, J.L. Hatfield, D.E. James, B.C. Vandenberg, J. Chen, T. Oster, J.D. Ross, and K.J. Cole. 2009b. STEWARDS watershed data system: System design and implementation. Transactions of the American Society of Agricultural and Biological Engineers 52(5):1523-1533.

USDA ARS (Agricultural Research Service). 2011a. Nashua Data Access. Treatment Effects for Measured Nashua Data. Tucson, AZ: USDA Agricultural Research Service, Southwest Watershed Research Center. http://apps. tucson.ars.ag.gov/nashua/docs/NashuaMeasured.pdf.

USDA ARS. 2011b. Nashua Data Access. Nashua Simulated vs. Measured. Tucson, AZ: USDA Agricultural Research Service, Southwest Watershed Research Center. http://apps.tucson.ars.ag.gov/nashua/docs/ NashuaSimulatedvMeasured.pdf.

USDA National Agricultural Statistics Service. 2003. Agricultural Statistics 2003. Washington, DC: United States Government Printing Office. http://www.nass. usda.gov/Publications/Ag_Statistics/2003/.

USEPA (US Environmental Protection Agency). 2007. Hypoxia in the Northern Gulf of Mexico: An update by the EPA Science Advisory Board. EPA-SAB-08-003. Washington, DC: US Environmental Protection Agency. 